\title{
The use of driving simulators for enhancing train driver's performance in terms of energy consumption
}

\author{
Pablo Salvador Zuriaga \\ Instituto del Transporte y Territorio. Universitat Politècnica de València \\ Carla García Román \\ Instituto del Transporte y Territorio. Universitat Politècnica de València \\ Juan Diego Pineda Jaramillo \\ Instituto del Transporte y Territorio. Universitat Politècnica de València \\ Ricardo Insa Franco \\ Instituto del Transporte y Territorio. Universitat Politècnica de València
}

\section{SUMMARY}

This paper presents a driving simulator to be used by train drivers for training their driving skills in terms of energy-efficiency. In railway operations, previous experiences have shown differences in energy consumption up to $20 \%$ among train drivers for the same journey in similar operational conditions. This shows great saving potentials in both economic and environmental terms. For this reason, railway companies wishing to become more efficient must encourage their train drivers to balance the energy consumption towards the minimum threshold. In this sense, driving simulators are a good complement for training courses on energy-saving best practices given to train drivers, where they can put into practice the learned contents.

The developed driving simulator consists in an Excel spreadsheet including an accurate energy consumption model, which was previously developed from real measurements on different train services. The fact of being an Excel spreadsheet provides a familiar interface to train drivers, making easier its use, and becomes an affordable tool for small and medium size freight private railway companies. Furthermore, the fact of being a non-real-time simulation makes possible to perform a journey of several hours in a few minutes, thus being able to test different driving strategies for the same train journey in a short time period. In this paper, the driving simulator was applied to the Valencia-Cuenca-Aranjuez railway line operated by Renfe Operadora with Diesel Multiple Units. The results are given in terms of fuel consumption, costs of fuel and $\mathrm{CO}_{2}$ emissions and enable train drivers to find by themselves the most efficient way to drive the train between two stations. Finally, this driving simulator may serve as the basis for training and evaluating train drivers in order to set up a bonus/penalty policy for rewarding the most efficient train drivers and achieve an overall energy consumption reduction.

\section{INTRODUCTION}

During last years, some strategies have been implemented with the aim to reduce energy consumption in railways. Among these, the most relevant ones are the design fo railway 
layouts with energy-efficient criteria, the improvement of rolling stock and the application of energy-saving strategies in railway operations (García Álvarez 2010).

The current energy consumption in railways depends on maximum speeds, gradients, loads and patterns of stops. Some authors have estimated the energy consumption and explored the improvements in rail transport systems through optimising the geometric alignment with applications of geographic information systems (GIS) (Lai and Schonfeld 2010), (Jha et al., 2007), global optimization of a rail transit line and its feeder bus system (Chien and Schonfeld, 1998), genetic algorithms applied for trains or crew scheduling (Dundar and Sahin 2011), (Liu et al., 2010), genetic algorithms for optimising the geometric alignment of the layout (Lai and Schonfeld, 2010), (Jha et al., 2007), (Samanta and Jha, 2011) phased development of rail transit routes (Cheng and Schonfeld, 2009), and simulation-based analysis of train controls under various track alignments (Kim and Chien, 2010).

In the field of driving strategies, authors focused on driving techniques and minimising energy consumption for freight trains (Lukaszewicz, 2000), (Lukaszewicz, 2001), (Lukaszewicz, 2004). Other studies indicate that it is possible save energy under the rigorous restriction of schedule time by keeping train speed uniform (Bai et al., 2009), and demonstrate a formal method for optimising traction energy consumption during a singletrain journey by trading-off reductions in energy against increases in running time (Bocharnikov et al., 2007).

There are different styles of driving the train, different types of preset speed within Automatic Train Operation (ATO) systems, regulation of railway traffic, the influence of the speed profile of a line, and the existence of temporary speed limitations (Salvador et al., 2016).

Regarding policies, some railway companies have started implementing energy-efficient driving training programs. (Sanftleben 2001), (Strößenreuther, 2005). Within these programs, train drivers are taught in energy saving driving, with different modules and lessons. As a part of the training, evaluation of efficient driving is performed in driving simulators. In these simulators, train drivers can practice the theoretical contents of the courses and receive some feedback about the achieved degree of efficiency. Especially interesting has been the project TRAINER, in which different railway administrations have implemented such training programs, e.g Trenitalia (Italy), NS (Netherlands), ZSSK (Slovaquia) and HSZ (Slovenia) (NL Agency s.f.). Parallel to this, TRAINER project also bets for the implementation of Long Term Agreements (LTA) between railway companies and Public Administrations. Within these LTA, energy-efficient measures may be stablished and regulated by identifying some objectives and the planning for their achievement.

Within this framework, this paper presents a train simulator purposely developed for diesel trains so that the drivers can perform different driving strategies and find the most efficient 
way to drive a train without compromising punctuality. First of all, the underlying equations in which the simulator is based are introduced. After this, the particular features and the appearance are presented, and some examples from real services are presented. Finally, the most important remarks are highlighted.

\section{MODEL DESCRIPTION}

The train simulator is based in two models. On the one hand, the dynamic model, which yields the movement variables, i.e. position, speed, acceleration, depending on the forces acting on the train at every instant. On the other hand, the consumption model which, depending on the demanded tractive effort, speed and other dynamic variables, obtains the throttle position, the engine revolutions and the fuel flow. Both models are solved upon the Finite Differences Method (FDM). This method solves differential equations step by step, assuming constant forces between subsequent steps. In addition, it is important to remark that all the parameters, tables and values presented have been calibrated and validated by means of a comprehensive monitoring campaign involving fuel measurements in real train services. (Salvador, et al. 2014)

These types of models usually operate in two different modes: time step or distance step. The most common way is time step. In this mode, the equation is solved assuming constant time increments $0, \Delta t, 2 \Delta t, 3 \Delta t, \ldots, n \Delta t$ and the solution of the equation is obtained at these instants. It has the advantage that the solution stability does not depend on the speed and the independent variable, i.e. the time, is evaluated at equal intervals. In the distance step approach, the equation is solved at homogeneous distance increments $0, \Delta x, 2 \Delta x, 3 \Delta x, \ldots$, $n \Delta x$. Although in this case, the solution stability depends on the train speed and the distance step, it has the advantage that the number of evaluated points for a given route remains invariant respect to the travel time. Furthermore, layout properties such as maximum speed, gradient or radius are evaluated in the same points, avoiding interpolation.

In this case, the distance approach has been chosen due to the fact that the number of calculation steps does not vary for a given route and therefore the instant location of singular points, i.e. stations, signals, etc. does not vary with the travel time.

\subsection{Dynamic model}

The dynamic model relates the tractive or braking effort with the rest of the forces acting on the train, upon Newton's $2^{\text {nd }}$ law in the movement direction. Therefore, at every distance step $j \Delta x$ Eq. (1) must be fulfilled.

$$
F_{e}=\sum_{k=1}^{n x} m_{k}\left(C_{m g} \ddot{x}+g i_{k}+\frac{8}{R_{k}}\right)+A+B \dot{x}+\frac{C T_{f}}{n x} \sum_{k=1}^{n x}\left(\dot{x}-v_{w} \cos \alpha_{k}\right)^{2}
$$


In this equation, the total train mass has been split into a chain of $k$ punctual masses $m_{\mathrm{k}}$, from 1 to $n x$, so that $n x$ is the result of dividing the total train length between the distance step:

$$
n x=\frac{l_{t}}{\Delta x}
$$

In this way, the train it is not considered as a punctual mass, but rather as a set of punctual masses separated a distance $\Delta x$ covering the total train length. This can be interesting for long trains since some parts may be in a downhill whereas some others may be in a flat stretch or in an uphill.

In the same way, $i_{\mathrm{k}}, R_{\mathrm{k}}$ and $\alpha_{\mathrm{k}}$ refer to the gradient, curve radius and angle between the layout and the wind for each $m_{\mathrm{k}}$, respectively.

The rest of the variables are shown in Table 1.

\begin{tabular}{|c|l|}
\hline$F_{\mathrm{e}}$ & Train tractive/braking effort $(\mathrm{kN})$ \\
\hline$C_{\mathrm{mg}}$ & Rotating mass coefficient \\
\hline$\ddot{x}$ & Longitudinal acceleration $\left(\mathrm{m} / \mathrm{s}^{2}\right)$ \\
\hline$g$ & Gravitational acceleration $\left(\mathrm{m} / \mathrm{s}^{2}\right)$ \\
\hline$\dot{x}$ & Train speed $(\mathrm{m} / \mathrm{s})$ \\
\hline$A$ & Mechanical resistance $(\mathrm{kN})$ \\
\hline$B$ & Air drag resistance, proportional to the speed $(\mathrm{kN} /(\mathrm{km} / \mathrm{h}))$ \\
\hline$C$ & Air drag resistance, proportional to the square of the speed $\left(\mathrm{kN} /(\mathrm{km} / \mathrm{h})^{2}\right)$ \\
\hline$T_{\mathrm{f}}$ & Tunnel factor \\
\hline$v_{\mathrm{w}}$ & Wind speed $(\mathrm{km} / \mathrm{h})$ \\
\hline
\end{tabular}

Table 1 - Significance of variables for Eq. (1).

Since the route is discretised in intervals of $\Delta x$, the energy consumption at every distance step $E_{\mathrm{j}}$ can be obtained in the following way:

$$
E_{j}=F_{e j} \Delta x
$$

The total energy consumption $E_{\mathrm{t}}$ is obtained by adding-up only those intervals in which the energy consumption is positive, i.e.

$$
E_{t}=\left.\sum_{j} E_{j}\right|_{E_{j}>0}
$$

In addition, the necessary time in order to cover each distance step $j \Delta x$ is given by the equations of the uniformly accelerated movement: 


$$
\Delta t_{j}=\frac{\dot{x}_{j}-\dot{x}_{j-1}}{\ddot{x}_{j-1}}
$$

Finally, the speed at the next instant is obtained again by means of the equations of the uniformly accelerated movement:

$$
\dot{x}_{j+1}^{2}=\dot{x}_{j}^{2}+2 \ddot{x}_{j} \Delta x
$$

\subsection{Consumption model}

For this case, a Diesel Multiple Unit (DMU) Series 592.200 has been modelled. This DMU consists of three cars, being motorised the extreme ones, with a total number of four diesel engines, two per car. Each engine moves its nearest bogie by means a hydrodynamic transmission. In these DMUs, the throttle has 6 notches, plus the idle position. In addition, the hydrodynamic transmission has two gears, whose behaviour is featured in terms of engine revolutions, train speed and fuel consumption. In this sense, table 2 shows the relations between the throttle position, the engine revolutions and the fuel flow for the first gear.

\begin{tabular}{|c|c|c|}
\hline Throttle position & Engine rpm & Fuel flow (1/h) \\
\hline 0 (idle) & 750 & 1.3 \\
\hline 1 & 870 & 4.2 \\
\hline 2 & 1130 & 10.0 \\
\hline 3 & 1350 & 18.0 \\
\hline 4 & 1600 & 26.2 \\
\hline 5 & 1850 & 39.7 \\
\hline 6 & 1950 & 60.6 \\
\hline
\end{tabular}

Table 2 - Relation between throttle position, engine rpm and fuel flow for the first gear

When the train reaches the speed of $90 \mathrm{~km} / \mathrm{h}$, the transmission automatically switches to second gear, and therefore behaves as shown in Table 3. In this table, $v$ stands up for the

\begin{tabular}{|c|c|c|}
\hline $\begin{array}{l}\text { Throttle } \\
\text { position }\end{array}$ & Engine rpm & Fuel flow (1/h) \\
\hline 0 & 750 & 1.33 \\
\hline 1 & \multirow{6}{*}{$11.7 v+378$} & 10 \\
\hline 2 & & 18 \\
\hline 3 & & 29 \\
\hline 4 & & 35 \\
\hline 5 & & 46 \\
\hline 6 & & $0.0287 v+6.4911$ \\
\hline
\end{tabular}
train speed.

Table 3 - Relation between throttle position, engine rpm and fuel flow for the second gear

Subsequently, total fuel consumption $V$ is obtained by summation of all the time increments obtained in Eq. (5) multiplied times the respective fuel flow $Q_{\mathrm{j}}$, i.e. 


$$
V=\sum_{j} Q_{j} \Delta t_{j}
$$

The relation between the tractive force from Eq. (1) and the correspondent throttle notch is shown in Fig. 1. In this figure, the traction-speed curves are drawn for each throttle position. The resistance to the movement with null gradient, according to Davis' coefficients, is shown as well.

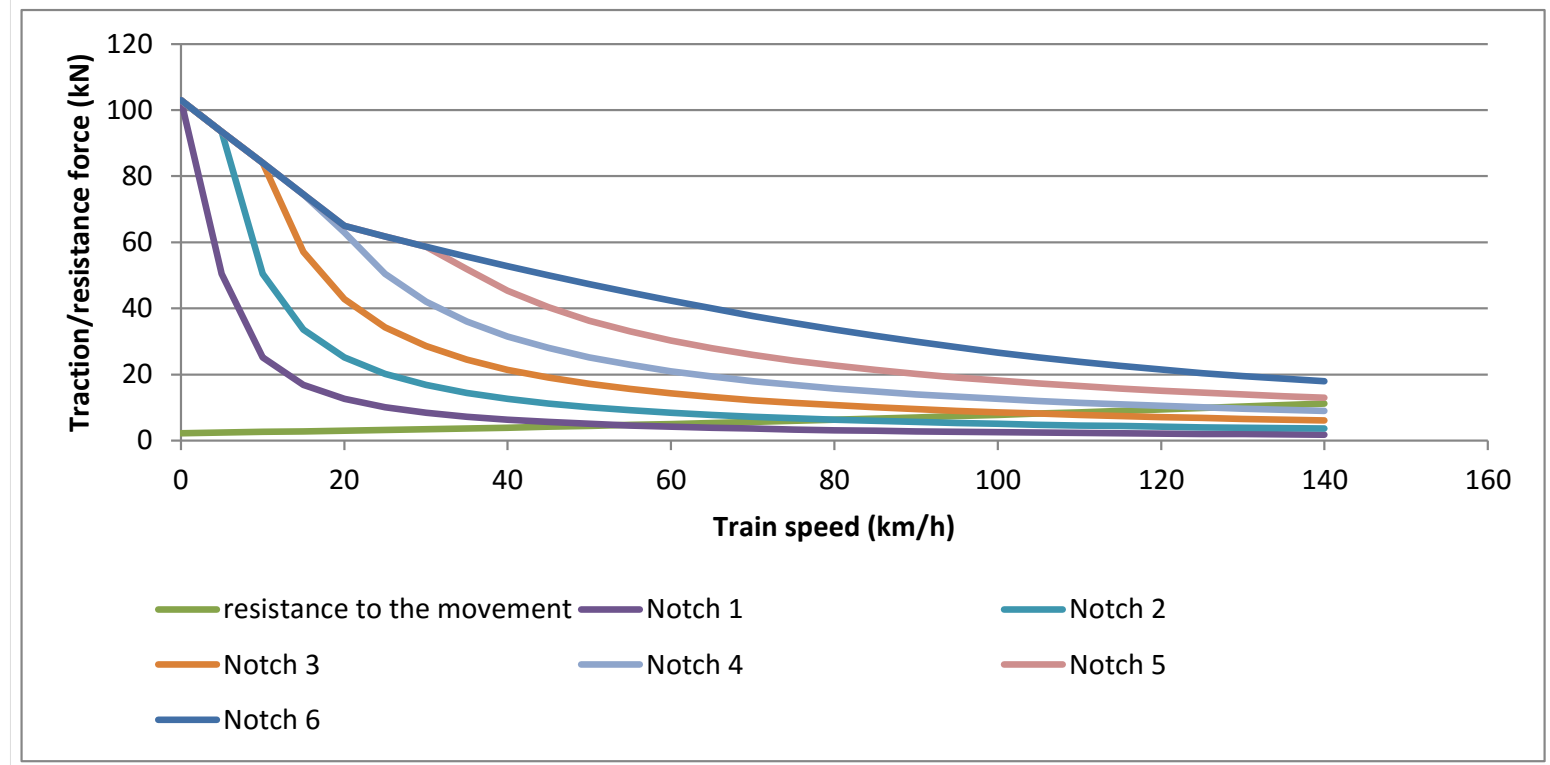

Fig. 1 - Traction-speed curves for each throttle position of DMU series 592.200.

\section{DRIVING SIMULATOR PROPERTIES}

\subsection{General description}

The proposed driving simulator is implemented in an Excel spreadsheet. Due to its simplicity, it can be accessible to many railway operators and train drivers, since it can be easily installed in their own computers. This is also an advantage to train drivers since most of them are already familiar with spreadsheets and therefore it is easier for them to learn how to use it. Moreover, the fact of being an off-line simulation, i.e. not real time, allows making a journey 6 to 8 times faster than in the reality, so in a few hours a train driver may practice different driving styles for a complete working journey and check his energy-efficiency.

In this simulator, the route is homogeneously discretised at intervals of $\Delta x=0.1 \mathrm{~km}$. This distance has proven to be a good compromise between accuracy of the FDM and the number of steps to cover a whole route. Because of the number of distance steps covering the whole route remains invariable, once a first driving style has been set up for the route, small changes in the driving styles are carried out with minor efforts. This allows practising and testing different driving strategies so as to check which one yields the best results in terms of energy 
efficiency and travel time.

\subsection{Appearance}

The driving simulator basically consists of three Excel sheets, all them placed in the same file. The first sheet (Fig. 2) includes the input data concerning the rolling stock properties (mass, tare, rotatory mass coefficient, traction curves, consumption ratios, etc.). Those cells which can be manipulated by the driver are highlighted in green, so as to set the appropriate train weight according to whether it runs empty, partially loaded, fully loaded, etc. This sheet also shows the results of the driving in terms of total fuel consumption, fuel consumption per kilometre, and travelling time. These results are highlighted in blue. The simulator is prepared for splitting the route into several stretches in case the train properties change or some partial results want to be obtained (e.g. switching carriages or wagons, change train drivers, etc.). For this example, the route Valencia-Aranjuez has been split in two parts in Cuenca, where train drivers usually change.

\begin{tabular}{|c|c|c|c|c|c|c|}
\hline & $\begin{array}{l}\text { Valencia- } \\
\text { Cuenca }\end{array}$ & $\begin{array}{l}\text { Cuenca- } \\
\text { Aranjuez }\end{array}$ & Route stretch & $\begin{array}{l}\text { Consumption } \\
\text { (I) }\end{array}$ & $\begin{array}{l}\text { Consumption } \\
\qquad(1 / \mathrm{km})\end{array}$ & $\begin{array}{c}\text { Time } \\
\text { (hh:mm) }\end{array}$ \\
\hline Mass (t) & 135 & 135 & Valencia-Cuenca & 327 & 1,65 & $2: 22: 36$ \\
\hline Tare $(\mathrm{t})$ & 131 & 131 & Cuenca-Aranjuez & 134 & 0,89 & $1: 39: 44$ \\
\hline rotatory mass $(\mathrm{t})$ & 7,205 & 7,205 & TOTAL & 461 & 1,32 & $4: 02: 20$ \\
\hline Accelerated mass ( $\mathrm{t}$ ) & 142,205 & 142,205 & & & & \\
\hline
\end{tabular}

Fig. 2 - Input and output data for the driving simulator

The second sheet includes the simulation itself, where the train path is obtained and displayed according to the FDM. In this sheet, each row corresponds to each distance step, whereas the different columns show the information according to Table 4.

\begin{tabular}{|c|c|c|}
\hline Col. & Variable & Description \\
\hline 1 & Station or gradient change & $\begin{array}{l}\text { Location of different reference points at the } \\
\text { route }\end{array}$ \\
\hline 2 & Throttle/brake position & $\begin{array}{l}\text { Throttle notch or brake position to be } \\
\text { selected by the train driver }\end{array}$ \\
\hline 3 & PK line $(\mathrm{km})$ & Existing mileposts along the line \\
\hline 4 & Speed $(\mathrm{km} / \mathrm{h})$ & Current train speed \\
\hline 5 & Speed limit change $(\mathrm{km} / \mathrm{h})$ & Change in the infrastructure speed limits \\
\hline 6 & $\begin{array}{l}\text { Speed limit infrastructure } \\
(\mathrm{km} / \mathrm{h})\end{array}$ & Speed limit imposed by the infrastructure \\
\hline 7 & Maximum speed $(\mathrm{km} / \mathrm{h})$ & $\begin{array}{l}\text { Maximum affordable speed including both } \\
\text { infrastructure and rolling stock limitations }\end{array}$ \\
\hline 8 & Departure/pass-through time & $\begin{array}{l}\text { Time from which the train leaves or passes } \\
\text { through the reference points specified in } \\
\text { column } 1 .\end{array}$ \\
\hline 9 & Stopping time (min) & $\begin{array}{l}\text { In case the train stops at any station, the time } \\
\text { it remains stopped }\end{array}$ \\
\hline 10 & Foreseen timetable & Train timetable as scheduled \\
\hline
\end{tabular}




\begin{tabular}{|c|l|l|}
\hline 11 & Difference $(\mathrm{min})$ & $\begin{array}{l}\text { Delay or advance in the actual path respect to } \\
\text { the scheduled one }\end{array}$ \\
\hline 12 & Altitude $(\mathrm{m})$ & Track layout altitude \\
\hline 13 & Gradient $(\mathrm{mm} / \mathrm{m}))$ & Track gradient \\
\hline 14 & Wind speed $(\mathrm{km} / \mathrm{h})^{\text {Speed of the wind }}$ \\
\hline 15 & ${\text { Wind direction }\left({ }^{\circ} \text { from North }\right)}^{\text {Direction from where the wind is blowing }}$ \\
\hline 17 & Tractive/braking effort $(\mathrm{kN})$ & $\begin{array}{l}\text { Net force exerted by the engines or the } \\
\text { brakes }\end{array}$ \\
\hline 18 & Total resistance $(\mathrm{kN})$ & Sum of the different resistance forces \\
\hline 19 & Time interval $(\mathrm{h})$ & Resulting acceleration from Eq. $(1)$ \\
\hline 20 & rpm & $\begin{array}{l}\text { Time employed in covering each distance } \\
\text { step }\end{array}$ \\
\hline 21 & Fuel flow per engine $(\mathrm{l} / \mathrm{h})$ & $\begin{array}{l}\text { Engine revolutions per minute } \\
\text { engine }\end{array}$ \\
\hline 22 & $\begin{array}{l}\text { Total fuel consumption } 4 \\
\text { engines }(\mathrm{l})\end{array}$ & $\begin{array}{l}\text { Cumulative fuel consumption from the } \\
\text { beginning for the total } 4 \text { engines }\end{array}$ \\
\hline 23 & Travelled distance $(\mathrm{km})$ & Travelled distance from the origin \\
\hline
\end{tabular}

Table 4 - Columns description for sheet 2 of the driving simulator

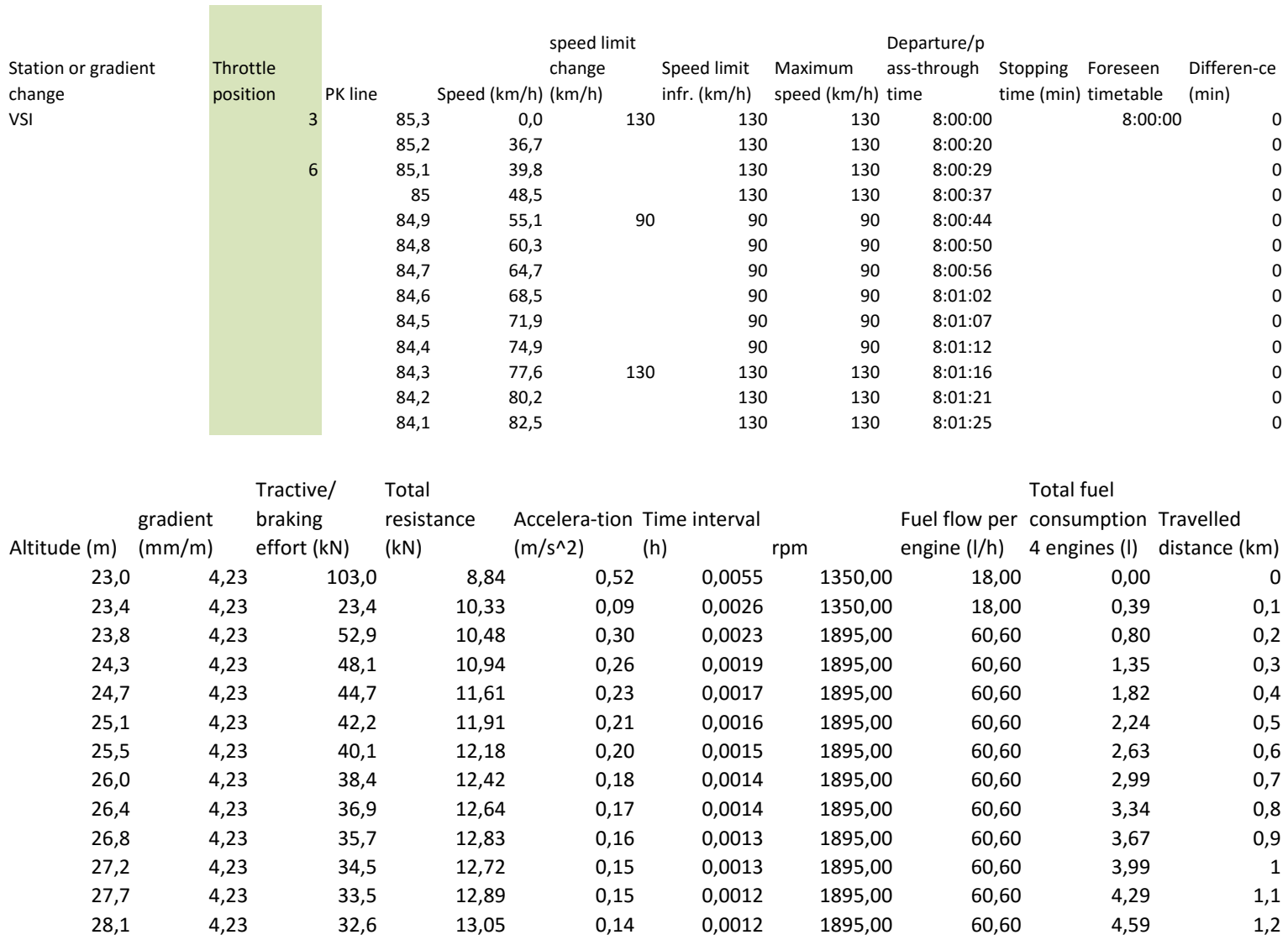

Fig. 3 - Driving spreadsheet appearance 


\subsection{Use}

In order to use the driving simulator, the following instructions must be observed. In the first place, the driver must set the train mass on sheet 1 for the different stretches in which the route is divided. After this, he can move on to sheet 2 and start the simulation. On sheet 2 , the first row is considered the start point, and therefore the values of travelled distance and speed are null. In this sheet, the driver only has to modify column \#2 "Throttle position", which is highlighted in light green. The spreadsheet is designed so that throttle positions must be entered only when they change. Otherwise, the spreadsheet understands to be in the last adopted position.

Depending whether the train is pulling of braking, the throttle position can adopt entire or decimal numbers, according to this type of DMU. For traction, the throttle may adopt 6 fixed positions, plus the idle (0). For braking, the service brake handle can be applied in a continuous range. In this case, the spreadsheet is calibrated so that the maximum braking effort is achieved at -4 , and the braking power increases linearly from 0 to -4 .

\subsection{Advices}

The present driving simulator has implemented three different advices in order to alert the train driver about some correct or wrong driving performances. The first one is the "ahead/delayed" indicator (Fig. 4). In column \#11 "difference" it appears the difference between the scheduled time and the real time. Whenever the train is ahead of time, the number is negative and the cell background is coloured green. Whenever the train is delayed, the number is positive and the cell background is coloured red. The time difference is updated as soon as a new reference regarding the foreseen timetable is reached, which normally happens at the stations.

\begin{tabular}{|c|c|c|c|c|c|c|c|c|c|c|c|c|}
\hline $\begin{array}{l}\text { Station or gradient } \\
\text { change }\end{array}$ & $\begin{array}{l}\text { Throttle } \\
\text { position }\end{array}$ & \multicolumn{2}{|c|}{ PK line } & \multicolumn{3}{|r|}{$\begin{array}{l}\text { speed limit } \\
\text { change }\end{array}$} & $\begin{array}{l}\text { Speed limit } \\
\text { infr. }(\mathrm{km} / \mathrm{h})\end{array}$ & $\begin{array}{l}\text { Maximum } \\
\text { speed }(\mathrm{km} / \mathrm{h})\end{array}$ & $\begin{array}{l}\text { Departure/p } \\
\text { ass-through } \\
\text { time }\end{array}$ & $\begin{array}{l}\text { Stopping } \\
\text { time (min) }\end{array}$ & $\begin{array}{l}\text { Foreseen } \\
\text { timetable }\end{array}$ & $\begin{array}{l}\text { Difference } \\
\text { (min) }\end{array}$ \\
\hline & & & & 80,5 & 119,1 & & 130 & 130 & $8: 03: 30$ & & & 0,31741508 \\
\hline & & & & 80,4 & 119,6 & & 130 & 130 & 8:03:33 & & & 0,31741508 \\
\hline & & & & 80,3 & 120,0 & & 130 & 130 & $8: 03: 36$ & & & 0,31741508 \\
\hline Aldaia & & & & 80 & 121,4 & 140 & 140 & 140 & $8: 03: 45$ & & 8:04:00 & $-0,25342489$ \\
\hline & & & & 79,9 & 121,6 & & 140 & 140 & $8: 03: 48$ & & & $-0,25342489$ \\
\hline & & & & 79,8 & 121,8 & & 140 & 140 & 8:03:51 & & & $-0,25342489$ \\
\hline & & & & 79,7 & 122,1 & & 140 & 140 & $8: 03: 54$ & & & $-0,25342489$ \\
\hline & & & & 79,6 & 122,3 & & 140 & 140 & 8:03:57 & & & $-0,25342489$ \\
\hline & & & & 79,5 & 122,5 & & 140 & 140 & $8: 04: 00$ & & & $-0,25342489$ \\
\hline
\end{tabular}

Fig. 4 - Fragment of the simulator showing a stretch in which the train is delayed and another in which it is ahead of time.

The second advice is the "overspeed" (Fig 5.). As soon as the train exceeds the speed limit, the cell or cells exceeding the speed limit are highlighted in red with a pink background. 
This tells the train driver to lower the notch position prior to reach the point where the speed has been exceeded. Finally, the last advice is the "excessive deceleration ratio" (Fig. 5). This is set up in order to prevent train drivers to apply an excessive braking effort leading to unrealistic or uncomfortable decelerations. Therefore, if the deceleration reaches a preestablished negative value, the value's background is coloured in red, thus alerting the train driver to reduce the braking effort. For this type of DMU, a threshold value of $-0.5 \mathrm{~m} / \mathrm{s}^{2}$ has been adopted.

\begin{tabular}{|c|c|c|c|c|c|c|c|c|c|c|c|}
\hline \multirow[t]{12}{*}{$\begin{array}{l}\text { Station or } \\
\text { gradient } \\
\text { change }\end{array}$} & \multirow[t]{12}{*}{$\begin{array}{l}\text { Throttle } \\
\text { position }\end{array}$} & & \multirow[t]{3}{*}{ PK line } & \multicolumn{3}{|c|}{$\begin{aligned} & \begin{array}{l}\text { speed limit } \\
\text { change }\end{array} \\
& \text { Speed }(\mathrm{km} / \mathrm{h})(\mathrm{km} / \mathrm{h})\end{aligned}$} & $\begin{array}{l}\text { Speed limit } \\
\text { infr. (km/h) }\end{array}$ & $\begin{array}{l}\text { Maximum } \\
\text { speed }(\mathrm{km} / \mathrm{h})\end{array}$ & $\begin{array}{l}\text { Departure/p } \\
\text { ass-through } \\
\text { time }\end{array}$ & $\begin{array}{l}\text { Difference } \\
\text { (min) }\end{array}$ & $\begin{array}{l}\text { Accelera-tion } \\
\left(\mathrm{m} / \mathrm{s}^{\wedge} 2\right) \\
0,02\end{array}$ \\
\hline & & & & 64,2 & 103,8 & & 130 & 130 & $8: 11: 50$ & $-0,253$ & 0,01 \\
\hline & & & & 64,1 & 104,0 & & 130 & 130 & $8: 11: 53$ & $-0,253$ & 0,01 \\
\hline & & & & 63,8 & 97,7 & & 130 & 130 & $8: 12: 04$ & $-0,253$ & $-0,34$ \\
\hline & & & & 63,7 & 93,1 & & 130 & 130 & $8: 12: 07$ & $-0,253$ & $-0,33$ \\
\hline & & 6 & & 63,6 & 88,4 & 90 & 90 & 90 & $8: 12: 11$ & $-0,253$ & 0,06 \\
\hline & & & & 63,5 & 89,2 & & 90 & 90 & $8: 12: 15$ & $-0,253$ & 0,05 \\
\hline & & & & 63,4 & 89,9 & & 90 & 90 & $8: 12: 19$ & $-0,253$ & 0,05 \\
\hline & & -4 & & 62,9 & 93,3 & & 90 & 90 & $8: 12: 39$ & $-0,253$ & $-0,86$ \\
\hline & & & & 62,8 & 80,4 & & 90 & 90 & $8: 12: 43$ & $-0,253$ & $-0,86$ \\
\hline & & & & 62,7 & 65,1 & & 90 & 90 & $8: 12: 48$ & $-0,253$ & $-0,85$ \\
\hline & & & & 62,6 & 45,1 & & 90 & 90 & $8: 12: 55$ & $-0,253$ & $-0,84$ \\
\hline
\end{tabular}

Fig. 5 - Fragment of the simulator showing a stretch with an overspeed (numbers highlighted in red with a pink background) and an uncomfortable deceleration (red background).

\subsection{Results}

Results of the driving simulator are displayed in the third spreadsheet. The first graph is the gear graphic corresponding to the train journey (Fig. 5). In this graphic there is the time of the day in the $x$-axis and the length of the line in the $y$-axis. Both the real and the scheduled (foreseen) journeys are plotted, so the driver can perceive if there has been any important deviation respect to the pre-defined schedule. 


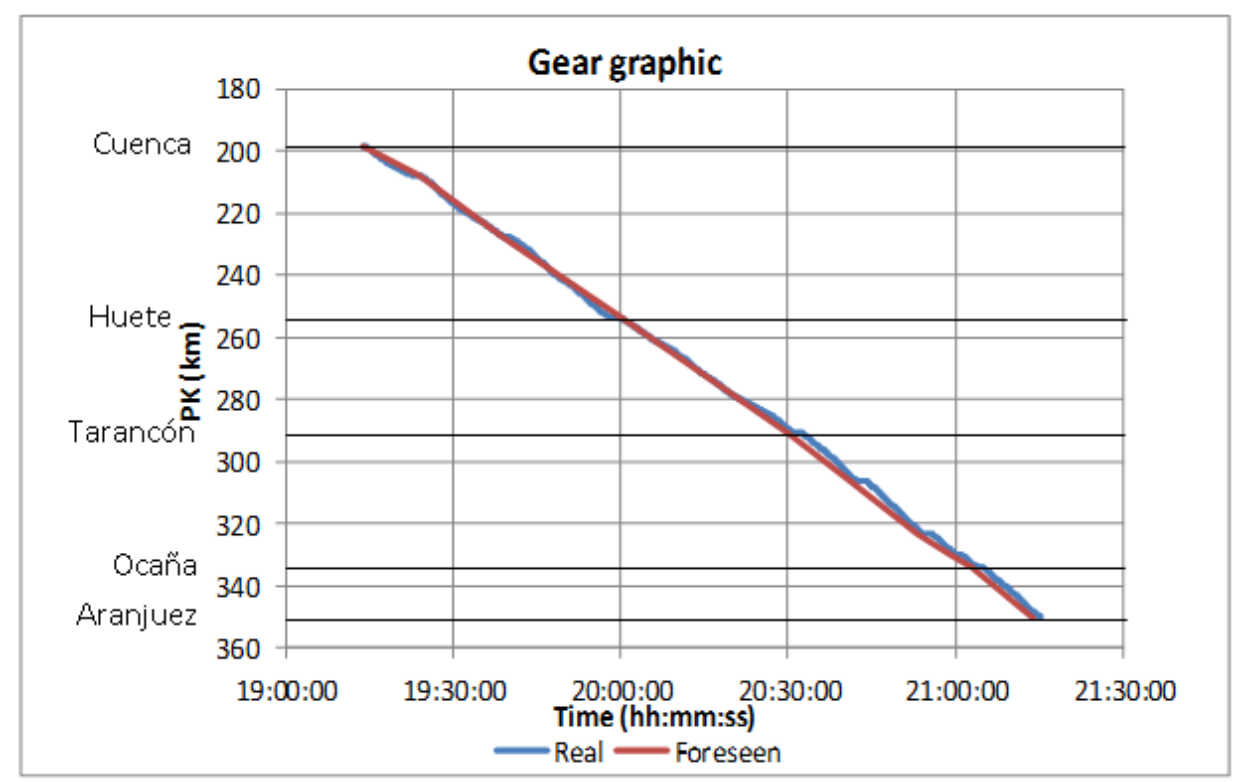

Fig. 5 - Example of a gear graphic for the stretch between Cuenca and Aranjuez

The second graph (Fig. 6) shows the actual speed profile, in comparison with the maximum permitted speed and the longitudinal profile of the line. This gives the train driver some feedback about the speed margin as the difference between the maximum speed and his speed, so he knows the potential for time recovering in case he is delayed or the speed variation in case he wants to smooth it in order to lower the energy consumption. The longitudinal profile is shown as well so as to have a reference for coasting points (i.e. not applying traction).

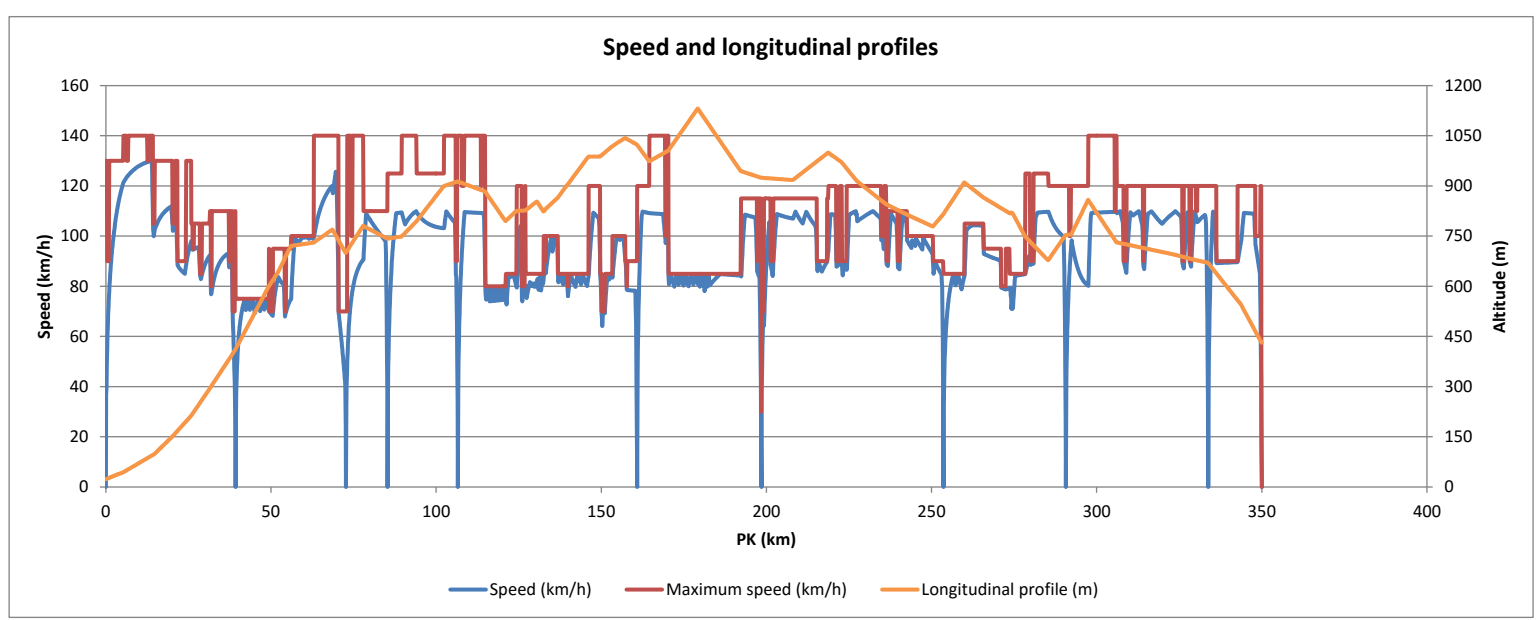

Fig. 6 - Actual speed vs. maximum speed and longitudinal profile

The third graph (Fig. 7) is analogous to the previous one, but in terms of throttle position. In this graph, the train driver may have more evidence about the location of coasting points, both for meeting a lower speed limit or for taking into account the downhills. 


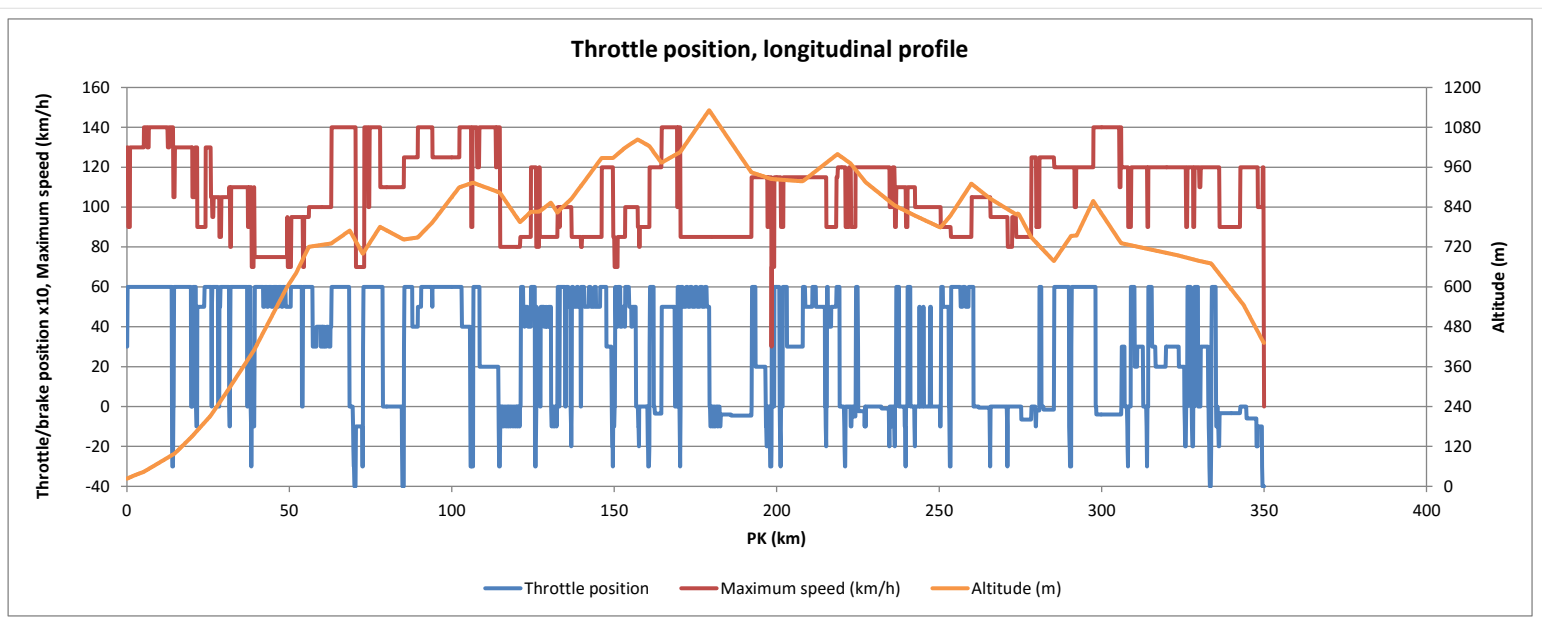

Fig. 7 - Throttle position vs. maximum speed and longitudinal profile

Finally, the last graph (Fig. 8) reports the instantaneous (flow) and accumulated (volume) fuel consumption for the journey. The accumulated fuel consumption takes into account the fuel consumed in all four diesel engines the DMU is provided with. In this graph, the throttle position has also been depicted so as to show the relation between the increment in fuel consumption and the throttle/brake manipulation. This raises the train driver's awareness in energy efficiency as he sees how his driving style is reflected on the energy consumption. In addition, he can see the stretches where the fuel consumption has been more relevant and these others where it is more suitable to achieve the largest savings.

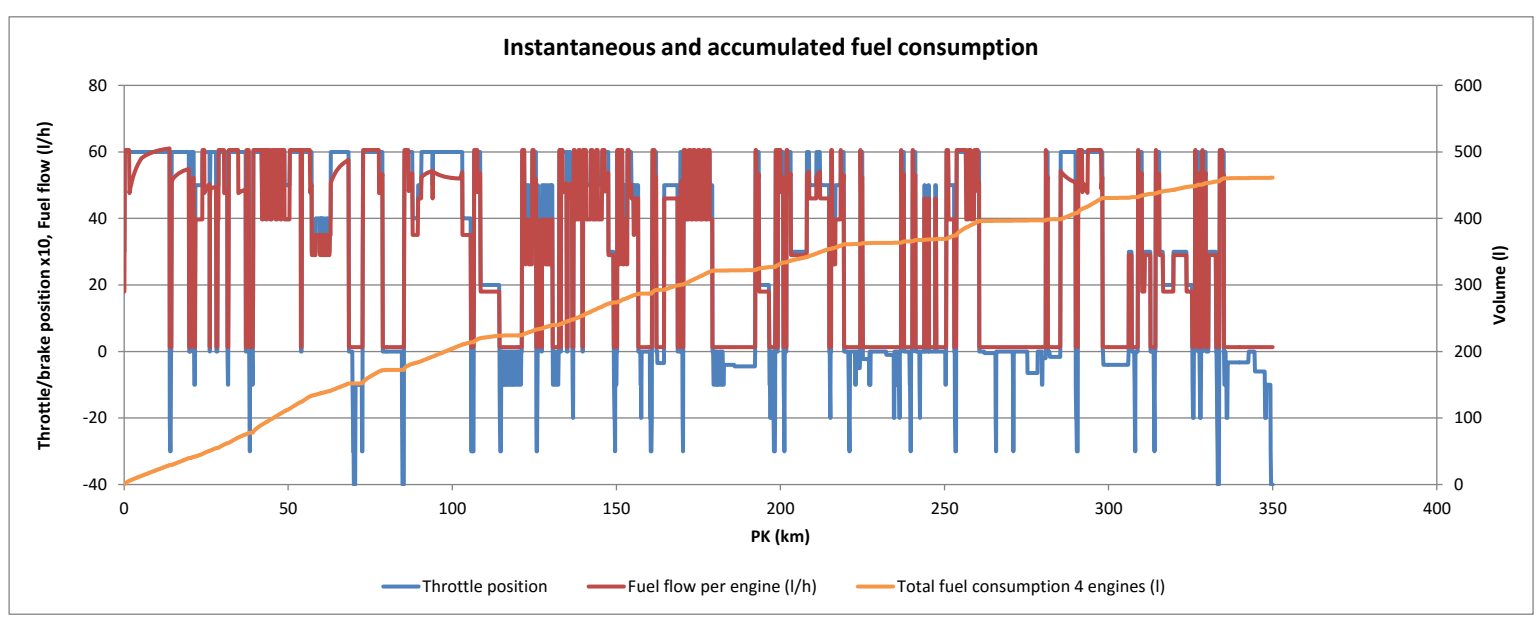

Fig. 7 - Throttle position vs. instantaneous and accumulated fuel consumption

\section{CONCLUSIONS}

A driving simulator for DMU has been presented in this paper. This driving simulator is implemented in an Excel spreadsheet and allows train drivers testing their driving styles in terms of time travel and fuel consumption. Despite the drawback of not being physically identical to a real DMU, this simulator accurately reproduces the train behaviour due to the dynamic and consumption models being implemented, which have been calibrated and 
validated by means of fuel consumption measurements under real operation services. It also has the advantages of being economically affordable by most of railway companies, including small rail freight operators; and being developed in a friendly environment such as a spreadsheet, which is familiar to most people. Furthermore, the fact of being a non real time simulation makes possible to test train journeys in 6 to 8 times less time than what it would really take, thus allowing testing different driving strategies in a given track stretch in a relative short time period.

The graphic results provide the train driver with some feedback regarding the actual gear graphic respect to the scheduled one, the speed profile and the throttle manipulation. Both are plotted together with the speed limits and the longitudinal profile so as to check the use of some energy-efficient driving strategies such as avoiding circulating at maximum speed, smoothing the speed profile and using downhills for coasting. In addition, the instantaneous and accumulated fuel consumption are presented together with the throttle/brake position so as to show the line stretches where higher consumptions occur and those allowing larger saving potentials. Finally, the numeric results, given in terms of total fuel consumption, average fuel consumption per kilometre and travel time may be stored in a historical data base in order to observe the train drivers' improvement in their driving skills.

\section{ACKNOLEDGEMENTS}

The authors would like to thank Renfe Operadora for its help and offer during the train tests. Project Funded by the Spanish Ministry of Economy and Competitiveness, Ref. TRA 201126602.

\section{REFERENCES}

Bai, Yun, Baohua Mao, Fangming Zhou, Yong Ding, and Chengbing Dong. "EnergyEfficient driving strategy for freight trains based on power consumption analysis." Journal of transportation systems engineering and information technology 9, no. 3 (2009): 43-50.

Bocharnikov, Y. V., A. M. Tobias, C. Roberts, S. Hillmansen, and C. J. Goodman. “Optimal driving strategy for traction energy on DC suburban railways." IET Electric Power Applications 1, no. 5 (2007): 675-682.

Cheng, W., and P. Schonfeld. "Phased development of rail transit routes." TRB Annual Meeting Compendium. Transportation Research Board, 2009.

Chien, S., and P. Schonfeld. "Joint optimization of a rail transit line and its feeder bus system.” J. Adv. Transp., 32(3), 1998: 253-284.

Dundar, S., and I. Sahin. "A genetic algorithm solution for train scheduling." TRB Annual Meeting Compendium. Transportation Research Board, 2011.

García Álvarez, A. High speed, energy consumption and emissions. Madrid: Study and Research Group for Railway Energy and emissions, 2010.

Jha, M. K., P. Schonfeld, and S. Samanta. "Optimizing rail transit routes with genetic algorithms and geographic information systems." J. Urban Plann. Dev., 133(3), 2007: 161-171. 
Kim, K., and S. I. Chien. "Simulation-based analysis of train controls under various track alignments." Journal of Transportation Engineering, 136(11), 2010: 937-948.

Lai, X., and P. Schonfeld. "Optimizing rail transit alignment connecting several major stations." TRB Annual Meeting Compendium. Transportation Research Board, 2010.

Liu, M., A. Haghani, and S. Toobaie. "A genetic Algorithm-based column generation approach to passenger rail crew scheduling." TRB Annual Meeting Compendium. Transportation Research Board, 2010.

Lukaszewicz, Piotr. "Driving techniques and strategies for freight trains." In Computers in railways VII, edited by J. Allan, C. A. Brebbia, R. J. Hill, G. Sciutto, \& S. Sone, 1065-1073. WIT Press, 2000.

Lukaszewicz, Piotr. "Energy consumption and running time for trains." Doctoral Thesis, Department of vehicle engineering, Royal University of Technology, Stockolm, 2001.

Lukaszewicz, Piotr. "Reducing power peaks and energy consumption in rail transit systems by simultaneous train running time control." In Computers in railways IX, edited by J. Allan, C. A. Brebbia, R. J. Hill, G. Sciutto, \& S. Sone, 885-894. WIT Press, 2004.

NL Agency. TRAINER Project Final Document. n.d. https://ec.europa.eu/energy/intelligent/projects/en/projects/trainer (accessed 322 , 2016).

Salvador, Pablo, Ignacio Villalba, Pablo Martínez, and Ricardo Insa. "Simulación del consumo de combustible en diferentes escenarios de explotación." In Monitorización, modelización y simulación del consumo energético en el ferrocarril, by Ricardo Insa, et al., 123-139. Valencia: Universitat Politècnica de València, 2016.

Salvador, Pablo, Ricardo Insa, Ignacio Villalba, Pablo Martínez Fernández, Rafael Sánchez Alandí, and Andrés Rovira. "Fuel Measurements in Diesel Multiple Units for Energy Management Purposes." 2nd International Conference on Railway Technology: Research, Development and Maintenance. Ajaccio (Corsica, France), 2014.

Samanta, S., and M. K. Jha. "Modeling a rail transit alignment considering different objectives." Transportation Research: Part A, 45(1), 2011: 31-45.

Sanftleben, D., Sonntag, H., Weber, K. "Verfahren Energiesparende Fahrweise - ESF." ETR, no. 50 (2001): 510-517.

Strößenreuther, H., Halbach, J. n.d.

Strößenreuther, H., Halbach, J. "Projekt EnergieSparen im Personenverkehr Energiekostenmanagement für die Traktionsenergie der Deutsche Bahn." ZEVrail Glasers Annalen 129 (2005): 356-362. 